Carlos Eduardo Godoy Junior ${ }^{1}$

ARMANDO ANTUNES JUNIOR

SIRLEI SIANI MORAIS ${ }^{1}$

Aarão Mendes Pinto-Neto ${ }^{1}$

LuCia COSTA-PAiva ${ }^{1}$

\title{
Accuracy of sonography and hysteroscopy in the diagnosis of premalignant and malignant polyps in postmenopausal women
}

\author{
Acurácia da ultrassonografia e da histeroscopia no diagnóstico de \\ pólipos endometriais pré-malignos e malignos na pós-menopausa
}

Original Article

Keywords

Polyps/surgery Endometrium/pathology Endometrium/ultrasonography Hysteroscopy/methods

Biopsy

Palavras-chave

Pólipos/cirurgia Endométrio/patologia Endométrio/ultrassonografia Histeroscopia/métodos Biópsia

\section{Abstract}

PURPOSE: To evaluate the accuracy of sonographic endometrial thickness and hysteroscopic characteristics in predicting malignancy in postmenopausal women undergoing surgical resection of endometrial polyps. METHODS: Five hundred twenty-one (521) postmenopausal women undergoing hysteroscopic resection of endometrial polyps between January 1998 and December 2008 were studied. For each value of sonographic endometrial thickness and polyp size on hysteroscopy, the sensitivity, specificity, positive predictive value (PPV) and negative predictive value (NPV) were calculated in relation to the histologic diagnosis of malignancy. The best values of sensitivity and specificity for the diagnosis of malignancy were determined by the Receiver Operating Characteristic (ROC) curve. RESULTS: Histologic diagnosis identified the presence of premalignancy or malignancy in $4.1 \%$ of cases. Sonographic measurement revealed a greater endometrial thickness in cases of malignant polyps when compared to benign and premalignant polyps. On surgical hysteroscopy, malignant endometrial polyps were also larger. An endometrial thickness of $13 \mathrm{~mm}$ showed a sensitivity of $69.6 \%$, specificity of $68.5 \%$, PPV of $9.3 \%$, and NPV of $98 \%$ in predicting malignancy in endometrial polyps. Polyp measurement by hysteroscopy showed that for polyps $30 \mathrm{~mm}$ in size, the sensitivity was $47.8 \%$, specificity was $66.1 \%$, PPV was $6.1 \%$, and NPV was $96.5 \%$ for predicting cancer. CONCLUSIONS: Sonographic endometrial thickness showed a higher level of accuracy than hysteroscopic measurement in predicting malignancy in endometrial polyps. Despite this, both techniques showed low accuracy for predicting malignancy in endometrial polyps in postmenopausal women. In suspected cases, histologic evaluation is necessary to exclude malignancy.

\section{Resumo}

OBJETIVO: Avaliar a acurácia da espessura endometrial ecográfica e características histeroscópicas em predizer malignidade em mulheres na pós-menopausa submetidas à ressecção cirúrgica de pólipos endometriais. MÉTODOS: Quinhentos e vinte e uma (521) mulheres na pós-menopausa submetidas à ressecção histeroscópica de pólipo endometrial entre janeiro de 1998 e dezembro de 2008 foram incluídas no estudo. Para cada valor de espessura endometrial ecográfica e tamanho dos pólipos na histeroscopia, a sensibilidade, a especificidade, valor preditivo positivo (VPP) e valor preditivo negativo (VPN) foram calculados em relação ao diagnóstico histológico de malignidade. Os melhores valores de sensibilidade e especificidade para o diagnóstico de malignidade foram determinados pela curva Receiver Operating Characteristic (ROC). RESULTADOS: $\bigcirc$ diagnóstico histológico identificou a presença de pré-malignidade ou malignidade em 4, $1 \%$ dos casos. A espessura endometrial medida por ultrassonografia em casos de pólipos malignos foi maior quando comparado com pólipos benignos e pré-malignos. Na histeroscopia os pólipos malignos também foram maiores. A espessura endometrial de 13 mm mostrou uma sensibilidade de 69,6\%, especificidade de 68,5\%, VPP de 9,3\% e VPN de 98\% para predizer malignidade em pólipo endometrial. A medida do pólipo por histeroscopia mostrou que para pólipos de $30 \mathrm{~mm}$ de tamanho, a sensibilidade foi de 47,8\%, a especificidade foi de 66, 1\%, VPP foi de 6, 1\% e VPN foi de 96,5\% para predizer o câncer. CONCLUSÕES: A espessura endometrial ultrassonográfica mostrou uma maior acurácia que a avaliação histeroscópica do tamanho do pólipo para predizer malignidade nessas lesões endometriais. Apesar disso, ambas as técnicas não mostraram boa acurácia para excluir a necessidade de fazer a avaliação histológica dos casos suspeitos.
Correspondence

Lucia Costa-Paivo

Department of Obstetics and Gynecology, Faculdade de Ciências Médicas, Universidade Estadual de Campinas - Unicamp

P.O. Box 6111

(EP: $13083-970$

Campinas (SP), Brazi

Received

$05 / 22 / 2012$

Accepted with modifications

05/14/2013
Study carried out at Universidade Estadual de Campinas - Unicamp - Campinas (SP), Brasil.

'Departamento de Tocoginecologia, Faculdade de Ciências Médicas, Universidade Estadual de Campinas - Unicamp - Campinas (SP), Brasil. 


\section{Introduction}

With the routine use of ultrasound for the investigation of abnormal uterine bleeding or postmenopausal bleeding over the last 20 years, the diagnoses of endometrial thickening and endometrial polyps have become more frequent. The prevalence of endometrial polyps ranges from 10 to $40 \%$ in women with abnormal uterine bleeding ${ }^{1-5}$. Furthermore, this disorder is found in up to $12 \%$ of asymptomatic women during routine gynecologic examinations ${ }^{6,7}$.

In postmenopausal women with risk factors associated with endometrial cancer, such as advanced age, obesity, hypertension, diabetes, tamoxifen use, or vaginal bleeding, hysteroscopic polypectomy has been adopted as a routine treatment.

The value of sonographic endometrial thickness, which allows us to predict malignant focal endometrial lesions with a higher level of diagnostic accuracy, remains controversial. Currently, postmenopausal patients with an endometrial thickness $\geq 5 \mathrm{~mm}$ are referred for endometrial biopsy performed via uterine curettage or surgical hysteroscopy, particularly when they exhibit associated vaginal bleeding. Hysteroscopy has revealed the presence of endometrial polyps in up to $74.3 \%$ of the patients with an endometrial thickness $>12 \mathrm{~mm}^{8}$. A search in the literature found no other studies that have assessed the value of ultrasound for the prediction of malignancy in focal endometrial lesions.

It is well known that the malignancy rate associated with endometrial polyps is low. In a meta-analysis performed by Lee et al. ${ }^{9}$, it was determined that malignant endometrial polyps were present in 0.8 to $8 \%$ of the patients, depending on the population studied and the methods used for diagnosis and resection ${ }^{10-17}$.

In postmenopausal women, there is a direct relationship between the size of endometrial polyps and the existence of atypical hyperplasia and endometrial carcinoma. A study performed by Rahimi et al. ${ }^{15}$ determined that polyps measuring $>1.5 \mathrm{~cm}$ carry a 3.6 -fold higher risk of malignancy compared with lesions with a smaller diameter.

\section{Methods}

From January 1998 to December 2008, 6,018 hysteroscopies were performed in the Prof. Dr. José Aristodemo Pinotti Women's Hospital - CAISM/Unicamp. From this total, 3,927 diagnostic hysteroscopies and 2,091 surgical hysteroscopies were excluded due to myomas, synechiae, removal of a foreign body, and endometrial ablation, resulting in 1,050 hysteroscopies performed, during this period, to remove endometrial polyps. From these,
180 hysteroscopies in which the histologic diagnosis of endometrial polyps was not confirmed, or the procedure was interrupted by complications or incomplete data in medical charts were excluded. Finally, we excluded 349 cases in which the procedure was performed to remove endometrial polyps in premenopausal women, resulting in 521 surgical hysteroscopies performed to remove polyps in postmenopausal women, the subject of our study (Figure 1).

The clinical, pathological, and sonographic data were obtained from medical chart review. This study included 521 postmenopausal women with or without abnormal bleeding who had previously received an ultrasound diagnosis of endometrial polyps, based on findings of focal endometrial thickening associated with the presence of a vascular pedicle. Diagnostic hysteroscopy was performed by using a Karl Storz hysteroscope with optical systems

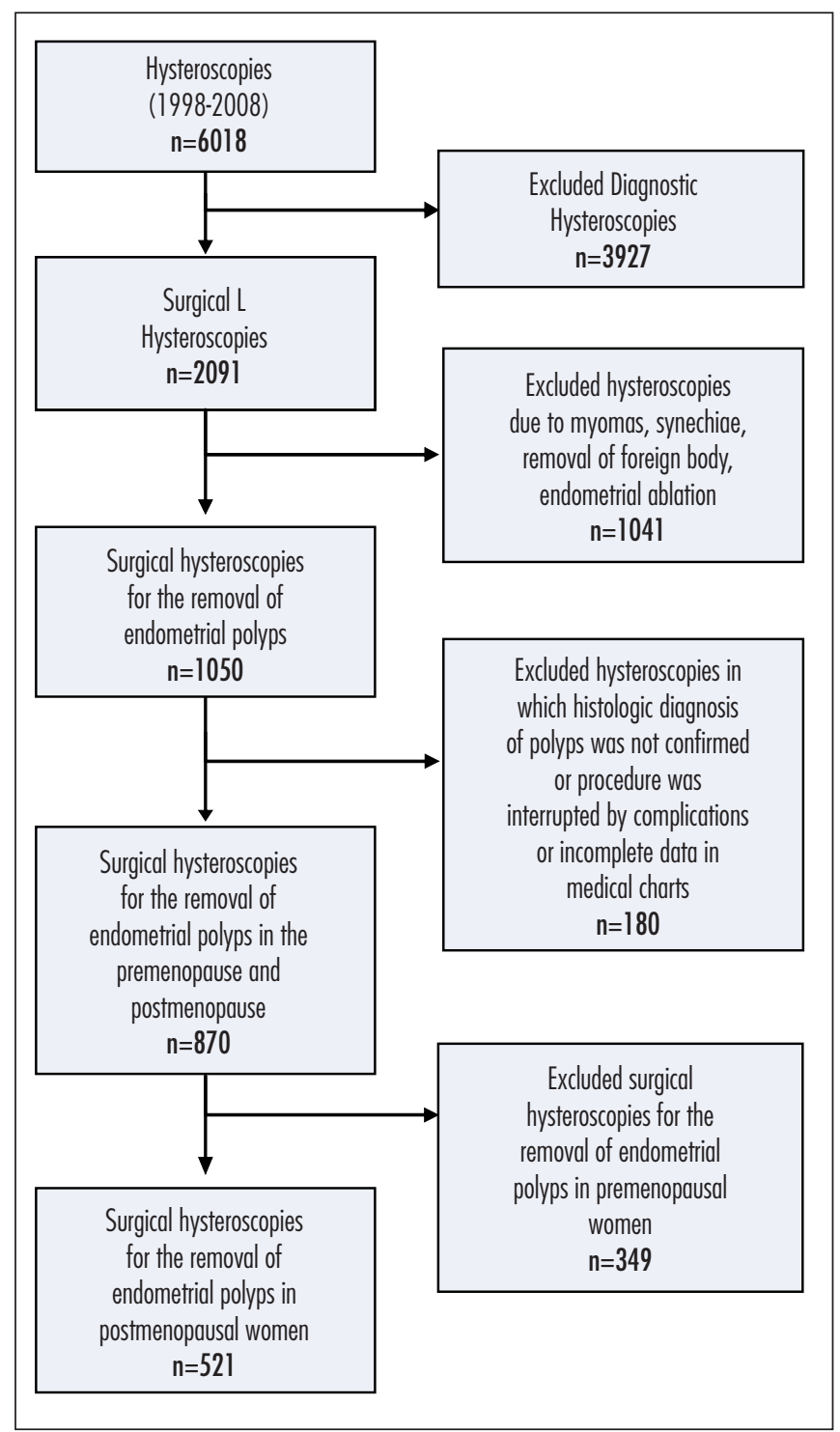

Figure 1. Flow chart. 
of $2.8 \mathrm{~mm}$. For distension of the uterine cavity, $\mathrm{CO}_{2}$ or saline solution was used. Through an evaluation of the endocervical canal, endometrial surface, vascularization, tubal ostia, the presence of endometrial polyps, myomas or synechiae were observed.

Surgical hysteroscopy with the patient under spinal anesthesia was performed using a $10 \mathrm{~mm}$ Karl Storz resectoscope. A glycine 1.5\% solution was used to distend the uterine cavity. Evaluation of the endocervical canal and endometrial cavity was performed. Resection of endometrial polyps was performed with loop electrocautery that relied on a monopolar electrical current.

Pathologists from the Department of Pathologic Anatomy of the Unicamp Medical School analyzed the endometrial samples obtained using hematoxylin and eosin staining. Polyps were classified as benign, non-atypical or atypical simple glandular hyperplasia, non-atypical or atypical complex glandular hyperplasia, and malignant.

This study was designed according to recommendations from the questionnaire Quality Assessment of Diagnostic Accuracy Studies (QUADAS) ${ }^{18}$, and approved by the Research Ethics Committee of FCM/Unicamp under number 769/2009.

\section{Statistical analysis}

Statistical analysis was performed by measurement of rates, means, and standard deviations. The sensitivity, specificity, positive predictive value (PPV), and negative predictive value (NPV) were calculated for different measures of endometrial thickness and polyp size upon hysteroscopy. Histologic diagnosis was used as the gold standard and the cut-off point (the point with the highest sensibility and specificity) was established by the methodology for the Receiver Operating Characteristic (ROC) curve. For statistical analysis, polyps were grouped according to histologic diagnosis into benign (benign polyps, non-atypical simple hyperplastic and non-atypical complex) or premalignant and malignant (atypical simple, atypical complex hyperplastic and carcinomatous), and the prevalence ratios and their respective confidence intervals were calculated. The significance level was set at $5 \%$. The SAS program version 9.2 was used for these estimates.

\section{Results}

Five hundred and twenty-one (521) postmenopausal women, with a mean age of 57.5 years $( \pm 10.6)$, were studied. Mean time since menopause was 12.4 years. There was a sonographic diagnosis of endometrial thickening $(>5 \mathrm{~mm})$ in $89.8 \%$ of cases. Histologic diagnosis identified the presence of premalignancy or malignancy in $4.1 \%$ of cases.
Sonographic measurement of the endometrial thickness in postmenopausal women undergoing hysteroscopic polypectomy revealed that mean thickness was $11.5 \mathrm{~mm}$ in benign polyps, $10.5 \mathrm{~mm}$ in premalignant polyps, and $17.4 \mathrm{~mm}$ in malignant polyps $(\mathrm{p}=0.002)$. Of the 16 malignant cases evaluated, 2 had endometrial thickness less than $5 \mathrm{~mm}$ on sonographic measurement (Table 1).

On surgical hysteroscopy, the median size of the benign polyps was $21.5 \mathrm{~mm}$, premalignant polyps 24.3 $\mathrm{mm}$, and malignant polyps $26.3 \mathrm{~mm}(\mathrm{p}=0.003)$ (Table 1).

To predict malignancy, the sensitivity, specificity, positive predictive value and negative predictive value were calculated for each value of sonographic endometrial thickness between 2 and $20 \mathrm{~mm}$, resulting in a diagnostic accuracy of $68.6 \%$. The best cut-off point established by the ROC curve was $13 \mathrm{~mm}$, showing a sensitivity of $69.6 \%$, specificity of $68.5 \%$, PPV of $9.3 \%$, and NPV of $98 \%$. On hysteroscopy, diagnostic accuracy for polyp size was $65.3 \%$ and the best cut-off point was $30 \mathrm{~mm}$ by the ROC curve, with a sensitivity of $47.8 \%$, specificity of $66.1 \%$, PPV of $6.1 \%$, and NPV of $96.5 \%$ (Table 2 and Figure 2).

With the purpose of determining the risk of malignancy in endometrial polyps according to a group of different risk factors, malignancy risk was calculated in correlation with the presence or absence of postmenopausal bleeding, endometrial thickness greater or less than 13 $\mathrm{mm}$ and polyp size larger or smaller than $30 \mathrm{~mm}$. For patients with vaginal bleeding, endometrial thickness less than $13 \mathrm{~mm}$ and polyps smaller than $30 \mathrm{~mm}$, the prevalence ratio showed a risk of malignancy of 14.41 (95\% CI 1.85-112.57), while for endometrial thickness

Table 1. Sonographic endometrial thickness ( $n=519)$ and polyp size by surgical hysteroscopy ( $n=521$ ) according to histologic diagnosis of endometrial polyp in postmenopausal women

\begin{tabular}{|c|c|c|c|c|}
\hline $\begin{array}{l}\text { Endometrial } \\
\text { thickness }\end{array}$ & $\begin{array}{c}\text { Benign } \\
\mathrm{n}=495 \\
\%\end{array}$ & $\begin{array}{c}\text { Premalignant } \\
n=08 \\
\%\end{array}$ & $\begin{array}{c}\text { Malignant } \\
n=16 \\
\%\end{array}$ & p-value* \\
\hline$<5 \mathrm{~mm}$ & 9 & 12 & 12 & \\
\hline 5.1 to $10 \mathrm{~mm}$ & 46 & 37 & - & \\
\hline 10.1 to $15 \mathrm{~mm}$ & 27 & 37 & 37 & \\
\hline 15.1 to $20 \mathrm{~mm}$ & 10 & 12 & 18 & \\
\hline$>20 \mathrm{~mm}$ & 6 & - & 31 & \\
\hline Mean \pm SD & $11.5 \pm 8.2$ & $10.5 \pm 4.7$ & $17.4 \pm 8.5$ & 0.002 \\
\hline Polyp size & $\begin{array}{c}\text { Benign } \\
n=498 \\
\%\end{array}$ & $\begin{array}{c}\text { Premalignant } \\
\mathrm{n}=07 \\
\%\end{array}$ & $\begin{array}{c}\text { Malignant } \\
n=16 \\
\%\end{array}$ & p-value* \\
\hline$<15$ mm & 38 & 28 & 25 & \\
\hline 15.1 to $20 \mathrm{~mm}$ & 24 & 14 & 25 & \\
\hline 20.1 to $25 \mathrm{~mm}$ & 2 & - & 6 & \\
\hline 25.1 to $30 \mathrm{~mm}$ & 21 & 42 & 18 & \\
\hline$>30 \mathrm{~mm}$ & 12 & 14 & 25 & \\
\hline Mean \pm SD & $21.5 \pm 13.9$ & $24.3 \pm 11.3$ & $26.3 \pm 13.2$ & 0.003 \\
\hline
\end{tabular}

*Mann-Whitney test. 
Table 2. Accuracy of ultrasound and hysteroscopy in diagnosing malignancy in endometrial polyps in postmenopausal women ( $\mathrm{n}=521)$

\begin{tabular}{|c|c|c|c|c|c|c|c|c|}
\hline \multirow[t]{2}{*}{ Cut-off point by ROC curve } & $\begin{array}{l}\text { Premalignant } \\
\text { /Malignant }\end{array}$ & Benign & \multirow{2}{*}{$\begin{array}{c}\text { Sensitivity } \\
(95 \% \mathrm{Cl})\end{array}$} & \multirow{2}{*}{$\begin{array}{c}\text { Specificity } \\
(95 \% \mathrm{Cl})\end{array}$} & PPV & NPV & Accuracy & \multirow{2}{*}{$\begin{array}{c}\text { PR } \\
(95 \% \mathrm{Cl})\end{array}$} \\
\hline & n & n & & & $\%$ & $\%$ & $\%$ & \\
\hline \multicolumn{9}{|l|}{ Endometrial thickness } \\
\hline$<13$ & 7 & 340 & $(50.8-88.4)$ & $(64.5-72.6)$ & & & & $(1.93-11)$ \\
\hline Total & 23 & 496 & & & & & & \\
\hline$<30$ & 12 & 328 & $(27.4-68.2)$ & $(61.9-70.2)$ & & & & $(0.78-3.86)$ \\
\hline Total & 23 & 496 & & & & & & \\
\hline
\end{tabular}

PPV: positive predictive value; NPV: negative predictive value; PR: prevalence ratio

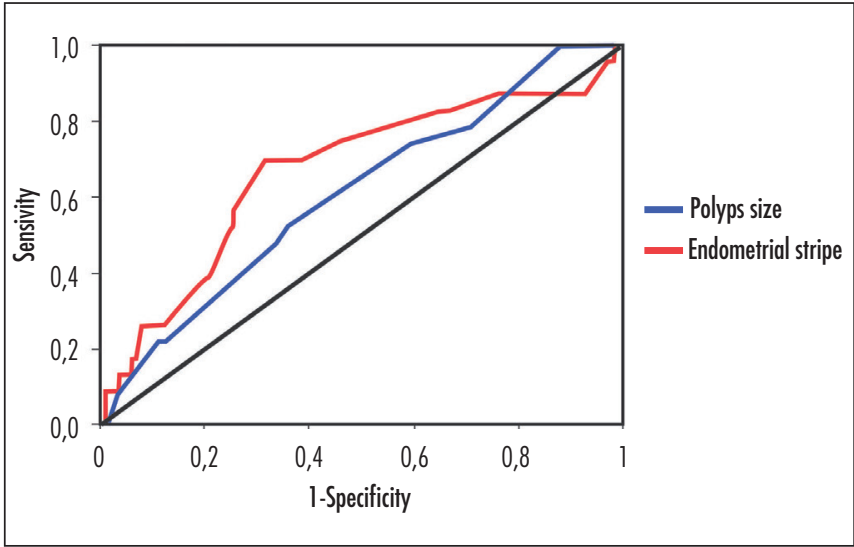

Figure 2. ROC curve for endometrial polyp size, endometrial stripe, and histologic diagnosis of malignancy

greater than $13 \mathrm{~mm}$ and polyps larger than $30 \mathrm{~mm}$, the risk was 32.71 (95\%CI 3.94-271.84). In the absence of postmenopausal bleeding, the assessment of endometrial thickness associated with polyp size did not significantly increase the risk of malignancy.

\section{Discussion}

This study used histological diagnosis as the gold standard and assessed the accuracy of sonographic endometrial thickness and hysteroscopic characteristics in predicting malignancy in women undergoing hysteroscopic resection of endometrial polyps. The results revealed a diagnostic accuracy of $68.6 \%$ for endometrial thickness and $65.3 \%$ for polyp size.

Satisfactory diagnostic methods for the prediction of malignancy in focal endometrial lesions are still lacking, and a histological investigation is required in all suspected cases.

In the postmenopausal period, different cut-off values for endometrial thickness have been proposed to determine whether additional investigation is required, particularly in asymptomatic women who carry a lower risk of malignancy compared with women with genital bleeding ${ }^{18-20}$. For focal endometrial lesions where the adjacent endometrium has an atrophic pattern, these cut-off values are poorly defined. There is little information about the role of sonography as an exclusive method for predicting malignancy in endometrial polyps.

In the present study, ultrasound measurement of endometrial thickness showed that the mean endometrial thickness was greater with malignant polyps than with benign polyps. An endometrial thickness of $13 \mathrm{~mm}$ showed the best sensitivity (69.6\%) and specificity (68.5\%) in predicting malignancy in endometrial polyps.

According to Dreisler et al. ${ }^{6}$, ultrasound made it possible to rule out the presence of benign focal endometrial lesions (polyps or submucous myomas) when the endometrial thickness was $<2.8 \mathrm{~mm}$, with a negative predictive value of $98.5 \%$. Grimbizis et al. ${ }^{21}$ observed a sensitivity of $41.8 \%$ and a specificity of $83.6 \%$ in the diagnosis of endometrial polyps using ultrasound examination. The author was unable to discriminate between benign, premalignant, and malignant focal lesions ${ }^{21}$.

In a study performed in the United Kingdom with 48,230 women undergoing transvaginal sonography to screen for endometrial cancer not associated with the presence of focal lesions, an endometrial thickness of $5.15 \mathrm{~mm}$ had a sensitivity of $80.5 \%$ and a specificity of $86.2 \%$ in predicting a malignancy. When a cut-off value of $10 \mathrm{~mm}$ was used further to investigate malignancy, the sensitivity was $54.1 \%$ and specificity was $97.2 \%$.

Among the diagnostic methods for investigating endometrial disease, hysteroscopy has the highest diagnostic efficacy. For hysteroscopic diagnosis of endometrial polyps, a study performed by Cepni et al. ${ }^{23}$ showed a sensitivity of $94 \%$ and a specificity of $58 \%$.

Few studies have evaluated the relationship between the size of the polyp and the risk of malignancy ${ }^{15-17,24,25}$. In this study, a size of $30 \mathrm{~mm}$ showed the best sensitivity $(47.8 \%)$ and specificity $(66.1 \%)$ in predicting malignancy in endometrial polyps. A meta-analysis conducted to evaluate the oncogenic potential of endometrial polyps 
in 10,552 patients identified only eight studies that evaluated the association between polyp size and risk of malignancy 9 . In four studies, larger polyps were directly associated with a greater risk of malignancy. According to Fernández-Parra et al. ${ }^{26}$, Goldstein et al. ${ }^{3}$, Shushan, Revel and Rojansky ${ }^{27}$, and Gregoriou et al. ${ }^{28}$, polyp size did not represent a risk factor for malignancy. The authors highlight that in this meta-analysis, polyp size was reported in different units of measurement (centimeters, millimeters, or grams) and data were not amenable; these factors hindered the analysis of this association.

The sensitivity of hysteroscopy for diagnosing any endometrial disease is $86 \%$, whereas that of ultrasound is $54 \% 22$. For the diagnosis of endometrial hyperplasia and endometrial cancer in the absence of focal lesions, the sensitivity of hysteroscopy was $33 \%$ and the specificity was $87 \%^{27}$. Small uterine lesions or functional changes with polypoid pattern in the endometrium may result in failure to identify focal lesions during hysteroscopic evaluation. Furthermore, malignant endometrial neoplasms may coexist with findings of benign endometrial polyps. For this reason, resection of endometrial polyps accompanied by guided biopsy of the adjacent endometrium is recommended in patients at risk ${ }^{29,30}$.
Data from the present study has shown that sonographic endometrial thickness and hysteroscopic measurement of endometrial polyps have a low level of accuracy in predicting malignancy in focal lesions. These methods alone are not sufficient to exclude the need for additional histological evaluation in suspected cases. There are still no satisfactory diagnostic methods for identifying patients that should undergo more judicious surgical resection. On the basis of the literature, an individualized approach to the treatment of patients with endometrial polyps is recommended, considering the associated risk factors for each patient. Symptomatic postmenopausal women should undergo hysteroscopic polyp resection while asymptomatic postmenopausal women should receive individualized therapy based on polyp size, presence of risk factors for malignancy, general clinical conditions, and their expectations from treatment ${ }^{31}$.

The aim of this study was to assess the accuracy of sonographic endometrial thickness and hysteroscopic characteristics in predicting malignancy in women undergoing hysteroscopic resection of endometrial polyps using histologic diagnosis as the gold standard.

\section{References}

1. Anastasiadis PG, Koutlaki NG, Skaphida PG, Galazios GC, Tsikouras PN, Liberis VA. Endometrial polyps: prevalence, detection, and malignant potential in women with abnormal uterine bleeding. Eur J Gynaecol Oncol. 2000;21 (2): 180-3.

2. Clevenger-Hoeft $M$, Syrop $C H$, Stovall DW, Van Voorhis BJ. Sonohysterography in premenopausal women with and without abnormal bleeding. Obstet Gynecol. 1999;94(4):516-20.

3. Goldstein SR, Zeltser I, Horan CK, Snyder JR, Schwartz LB. Ultrasonography-based triage for perimenopausal patients with abnormal uterine bleeding. Am J Obstet Gynecol. 1997;177(1):102-8.

4. Nagele F, O'Connor H, Davies A, Badawy A, Mohamed H, Magos A. 2500 outpatient diagnostic hysteroscopies. Obstet Gynecol. 1996;88(1):87-92.

5. Van Bogaert L. Clinicopathologic findings in endometrial polyps. Obstet Gynecol. 1988;71(5):771-3.

6. Dreisler E, Stampe Sorensen S, Ibsen PH, Lose G. Prevalence of endometrial polyps and abnormal uterine bleeding in a Danish population aged 20-74 years. Ultrasound Obstet Gynecol. 2009;33(1):102-8.

7. Lieng M, Istre O, Sandvik L, Qvigstad E. Prevalence, 1-year regression rate, and clinical significance of asymptomatic endometrial polyps: cross-sectional study. J Minim Invasive Gynecol. 2009;16(4):465-71.

8. Schmidt T, Breidenbach M, Nawroth F, Mallmann P, Beyer IM, Fleisch MC, et al. Hysteroscopy for asymptomatic postmenopausal women with sonographically thickened endometrium. Maturitas. 2009;62(2):176-8.

9. Lee SC, Kaunitz AM, Sanchez-Ramos L, Rhatigan RM. The oncogenic potential of endometrial polyps: a systematic review and meta-analysis. Obstet Gynecol. 2010;1 16(5):1 197-205.

10. Martínez MA, Jou P, Nonell R, Cardona M, Alonso I, Vanrell JA. Pólipos endometriales: riesgo de malignización y correlación clínico-anatómica. Prog Obstet Ginecol. 2004;47(1 1):506-10.

11. Antunes A Jr, Costa-Paiva L, Arthuso M, Costa JV, Pinto-Neto AM. Endometrial polyps in pre- and postmenopausal women: factors associated with malignancy. Maturitas. 2007;57(4):415-21.

12. Savelli $L$, De laco $P$, Santini D, Rosati F, Ghi T, Pignotti E, et al. Histopathologic features and risk factors for benignity, hyperplasia, and cancer in endometrial polyps. Am J Obstet Gynecol. 2003; 188(4):927-31.

13. Lieng $M$, Istre $O$, Qvigstad E. Treatment of endometrial polyps: a systematic review. Acta Obstet Gynecol Scand. 2010;89(8):9921002.

14. Baiocchi G, Manci N, Pazzaglia M, Giannone L, Burnelli L, Giannone $E$, et al. Malignancy in endometrial polyps: a 12-year experience. Am J Obstet Gynecol. 2009;201(5):462.e 1-4.

15. Rahimi S, Marani C, Renzi C, Natale ME, Giovannini P, Zeloni R. Endometrial polyps and the risk of atypical hyperplasia on biopsies of unremarkable endometrium: a study on 694 patients with benign endometrial polyps. Int J Gynecol Pathol. 2009;28(6):522-8. 
16. Ben-Arie A, Goldchmit C, Laviv Y, Levy R, Caspi B, Huszar M, et al. The malignant potential of endometrial polyps. Eur J Obstet Gynecol Reprod Biol. 2004;1 15(2):206-10.

17. Ferrazzi E, Zupi E, Leone FP, Savelli L, Omodei U, Moscarini M, et al. How often are endometrial polyps malignant in asymptomatic postmenopausal women? A multicenter study. Am J Obstet Gynecol. 2009;200(3):235.e 1-6.

18. Whiting P, Rutjes AW, Reitsma JB, Bossuyt PM, Kleijnen J. The development of QUADAS: a tool for the quality assessment of studies of diagnostic accuracy included in systematic reviews. BMC Med Res Methodol. 2003;3:25.

19. Osmers R, Völksen M, Schaver A. Vaginosonography for early detection of endometrial carcinoma? Lancet. 1990;335(8705): 1569-71.

20. Seelbach-Göbel B, Rempen A, Kristen P. [Vaginal sonography of the endometrium in postmenopause. Initial results of a prospective study]. Gynakol Rundsch. 1991;31 (Suppl 2):253-5. German.

21. Grimbizis GF, Tsolakidis D, Mikos T, Anagnostou E, Asimakopoulos $E$, Stamatopoulos $P$, et al. A prospective comparison of transvaginal ultrasound, saline infusion sonohysterography, and diagnostic hysteroscopy in the evaluation of endometrial pathology. Fertil Steril. 2010;94(7):2720-5

22. Weigel M, Friese K, Strittmatter HJ, Melchert F. [Ultrasound assessment of the postmenopausal endometrium. Is measuring thickness adequate?] Ultraschall Med. 1994;15(3):117-21. German.

23. Cepni I, Ocal P, Erkan S, Saricali FS, Akbas H, Demirkiran F, et al. Comparison of transvaginal sonography, saline infusion sonography and hysteroscopy in the evaluation of uterine cavity pathologies. Aust N Z J Obstet Gynaecol. 2005;45(1):30-5.

24. Jacobs I, Gentry-Maharaj A, Burnell M, Manchanda R, Singh N, Sharma A, et al. Sensitivity of transvaginal ultrasound screening for endometrial cancer in postmenopausal women: a case-control study within the UKCTOCS cohort. Lancet Oncol. 2011;12(1):38-48.

25. Wang JH, Zhao J, Lin J. Opportunities and risk factors for premalignant and malignant transformation of endometrial polyps: management strategies. J Minim Invasive Gynecol. 2010;17(1):53-8.

26. Fernández-Parra J, Rodríguez Oliver A, López Criado S, Parrilla Fernández F, Montoya Ventoso F. Hysteroscopic evaluation of endometrial polyps. Int J Gynaecol Obstet. 2006;95(2):144-8.

27. Shushan A, Revel A, Rojansky N. How often are endometrial polyps malignant? Gynecol Obstet Invest. 2004;58(4):212-5.

28. Gregoriou O, Konidaris S, Vrachnis N, Bakalianou K, Salakos N, Papadias $\mathrm{K}$, et al. Clinical parameters linked with malignancy in endometrial polyps. Climacteric. 2009;12(5):454-8.

29. Krampl E, Bourne T, Hurlen-Solbakken $H$, Istre O. Transvaginal ultrasonography sonohysterography and operative hysteroscopy for the evaluation of abnormal uterine bleeding. Acta Obstet Gynecol Scand. 2001;80(7):616-22.

30. Salim S, Won H, Nesbitt-Hawes E, Campbell N, Abbott J. Diagnosis and management of endometrial polyps: a critical review of the literature. J Minim Invasive Gynecol. 201 1;18(5):569-81.

31 . American Association of Gynecologic Laparoscopists. AAGL practice report: practice guidelines for the diagnosis and management of endometrial polyps. J Minim Invasive Gynecol. 2012;19(1):3-10. 